\title{
The Right of Innocent Passage: The Challenge of the Proliferation Security Initiative and the Implications for the Territorial Waters of the Åland Islands
}

\author{
Pirjo Kleemola-Juntunen
}

\section{Introduction}

Modern law of the sea developments has raised questions relating to the application of treaty-based, non-formalised and non-treaty based regulations of cooperation, as well as norms of international customary law and State practice, which have been introduced after the 1921 Convention relating to the Non-fortification of and Neutralisation of the Åland Islands. ${ }^{1}$ The Åland Islands are unique within Europe, and their legal status cannot be compared to anywhere else in the region. The Åland archipelago is located within the entrance to the Gulf of Bothnia, between Finland and Sweden. As a result of the geographical connection to the Finnish mainland, the demilitarised and neutralised sea area of the Åland Islands is located within the territorial sea and internal waters of Finland. The Åland Strait, a narrow stretch of water connecting the Gulf of Bothnia with the Baltic Sea between the Åland Islands

This chapter is written as a part research project "Demilitarisation in an increasingly militarised world. International perspectives in a multilevel framework - the case of the Aland Islands". The research project is a co-operation between the Åland Islands Peace Institute (ÅIPI) and the University of Lapland and its Arctic Center in Rovaniemi (Finland). The Project is funded by the KONE Foundation. The writer is working as a Post-doc researcher in the Project.

${ }^{1}$ Convention relating to the Non-fortification of and Neutralisation of the Aaland Islands, adopted on 20 October 1921 and entered into force 6 April 1922. 9 LNTS 211. Parties to the Convention include: Denmark, Estonia, Finland, France, Germany, Great Britain, Iceland (Union with Denmark in 1921) Italy, Latvia, Poland and Sweden.

P. Kleemola-Juntunen $(\bowtie)$

Åland Islands Peace Institute, Åland, Finland

Northern Institute for Environmental and Minority Law, Arctic Centre, University of Lapland,

Rovaniemi, Finland

e-mail: pirjo.kleemola-juntunen@ulapland.fi 
and Sweden is a particularly important sea route. ${ }^{2}$ In terms of the law of the sea, the development of weapon technology has made warships more effective and enhanced their roles in warfare. Coastal States have also become more alert to the threat of nuclear-powered ships and ships carrying nuclear weapons. Furthermore, in the twenty-first century, the number of unlawful activities at sea has become a challenge to maritime trade. Today, the most significant of the unlawful activities is terrorism, and as a result there has been an increase in the interest shown in maritime security by the international community. Traditionally, weapons of mass destruction (WMD) have been in the hands of States. Recently, it has become possible for non-State actors to acquire WMD and related materials, and this has increased the probability of unlawful trafficking of WMD across the world. The demilitarised sea around the Aland Islands is at risk of this unlawful behaviour.

The Proliferation Security Initiative came about following the terrorist attacks of 11 September 2001 and after the So San incident. ${ }^{3}$ The Proliferation Security Initiative (PSI) is a cooperation arrangement that aims to prevent the proliferation of weapons of mass destruction, their delivery systems and related materials. It was introduced by the United States as a measure to prevent terrorist attacks in 2003, and the principle has been endorsed by the UN Security Council Resolutions adopted under Chapter VII of the UN Charter, ${ }^{4}$ as well as by the adoption of the 2005 Protocol to the Convention for the Suppression of Unlawful Acts Against the Safety of Maritime Navigation. ${ }^{5}$ The 2005 SUA Protocol was the first treaty that recognised the trafficking of WMD and related materials as illegal behaviour. ${ }^{6}$ As a

\footnotetext{
${ }^{2}$ According to HELCOM publication Shipping Accidents in the Baltic Sea in 2013 14,433 ships on the Åland West route and 1397 ships on the Åland East route have crossed AIS fixed lines through the Åland Strait during the year 2013, HELCOM (2014), pp. 3-7.

${ }^{3}$ The missiles of North Korean origin were in transit to Yemen by a ship flying under Cambodian flag. The So San was intercepted and boarded by the Spanish Navy relying on U.S. intelligence and subsequently released due to lack of legal support for the seizure. See more Byers (2004), pp. 526-527.

${ }^{4}$ UN Security Council Resolutions 1540 (2004), 1673 (2006), 1810 (2008), 1977 (2011), 2055 (2012).

${ }^{5}$ Protocol to the Convention for the Suppression of Unlawful Acts Against the Safety of Maritime Navigation and Protocol for the Suppression of Unlawful Acts Against the Safety of Fixed Platforms on the Continental Shelf adopted on 1 November 2005 and entered into force on 28 July 2010 ('2005 SUA Protocol').

${ }^{6}$ Durkalec (2012), p. 14, Protocol of 2005 to the Convention for the Suppression of Unlawful Acts Against the Safety of Maritime Navigation, at https://www.unodc.org/tldb/pdf/Protocol_2005_ Convention_Maritime_navigation.pdf. The Achille Lauro incident of 1985 gave rise to the Suppression of Unlawful Acts Against the Safety of Maritime Navigation and Protocol for the Suppression of Unlawful Acts Against the Safety of Fixed Platforms on the Continental Shelf (the SUA Convention and SUA Protocol), adopted 10 March 1988 and entered into force 1 March 1992, as a measure to prevent unlawful acts which threaten the safety of ships and security of passengers and crew. IMO Convention for the Suppression of Unlawful Acts Against the Safety of Maritime Navigation and Protocol for the Suppression of Unlawful Acts Against the Safety of Fixed Platforms on the Continental Shelf, March 13, 1988, entered into force on March 1, 1992, IMO Doc SUA/CONF/15, ILM 27 (1988), pp. 672-684.
} 
non-treaty-based partnership of States, the Proliferation Security Initiative (PSI) is aimed to complement existing international arms control arrangements such as the Treaty on the Non-Proliferation of Nuclear Weapons (NPT), ${ }^{7}$ the Chemical Weapons Convention (CWC $)^{8}$ and the Biological Weapons Convention (BWC). ${ }^{9}$ The aim of the PSI participants was to stop the illicit transport of WMD on the oceans. The major problem as regards illicit trafficking is not the ready-made WMD but is more often the trafficking of components, technologies and production materials related to WMD. The problem with these items is that majority of them can have civilian as well as military end uses. Such dual-use materials pose a problem because they are mostly used for peaceful purposes, and in these circumstances their transportation is legal. The main concern of the PSI is to prevent States and non-State actors of proliferation concern from acquiring the materials to build WMD. ${ }^{10}$

Although the PSI is a political initiative, after the adoption of the Statement of Interdiction Principles that sets forth the objectives and working methods of the PSI, it has implications for the existing law of the sea. ${ }^{11}$ The Statement of Interdiction Principles says that PSI activities will not violate international law. However, subparagraph 4 (d) (1) of the Statement of Interdiction Principles calls on participants to take appropriate actions to stop and/or search in their territorial seas vessels that are 'reasonably suspected' of carrying such cargoes to or from States or non-State actors of proliferation concern and to seize such cargoes that are identified.

The requirement in subparagraph 4 (d) (1) is problematic because although coastal States have sovereignty over their territorial seas, it is limited by Article 19 of UNCLOS, which regulates the right of innocent passage of foreign vessels. However, today 105 States are participants to the PSI, and when they act unilaterally they give rise to new State practice. If several flag States were to accept boarding by a coastal State of a ship exercising the right of innocent passage because the ship was suspected of the illegal trafficking of WMD without prior

\footnotetext{
${ }^{7}$ Treaty on the Non-Proliferation of Nuclear Weapons, adopted on 1 July 1968 and entered into force on 5 March 1970 at https://www.iaea.org/sites/default/files/publications/documents/infcircs/ 1970/infcirc140.pdf.

${ }^{8}$ Chemical Weapons Convention, adopted on 13 January 1993 and entered into force on 29 April 1997 at http://disarmament.un.org/treaties/t/cwc/text.

${ }^{9}$ Biological Weapons Convention, adopted on 10 April 1972 and entered into force on 26 March 1975 at http://disarmament.un.org/treaties/t/bwc/text.

${ }^{10}$ US Department of State Proliferation Security Initiative at http://www.state.gov/t/isn/c10390. htm, Logan (2005), p. 255, Prosser and Scoville (2004), Beck (2004), p. 16 at http://www.uga.edu/ cits/documents/pdf/monitor/monitor_sp_2004.pdf.

"The PSI participants are committed to the following interdiction principles to establish a more coordinated and effective basis through which to impede and stop shipments of WMD, delivery systems, and related materials flowing to and from states and non-state actors of proliferation concern, consistent with national legal authorities and relevant international law and frameworks, including the UN Security Council." Fact Sheet The White House, Office of the Press Secretary (2003).

${ }^{11}$ Winner (2005), p. 130.
} 
permission of the flag State, it would weaken the existing legal norm relating to right of innocent passage that has its roots far back in history. This is especially true because the PSI is targeted to merchant ships, and the origin of the concept is freedom of navigation of merchant ships over the oceans. ${ }^{12}$ Thus, at least in theory, the new State practice of the provision regulating innocent passage would narrow the scope of the right of innocent passage.

Although the sovereignty of coastal States extends to the territorial seas, such sovereignty includes some restrictions that do not exist for a State's land-based territory or its internal waters. On the territorial sea, all foreign ships enjoy the right of innocent passage, an old principle concept of the law of the sea, today codified in the UN Law of the Sea Convention. As long as the passage is innocent, the coastal State has restricted jurisdiction to interfere with the passage. It seems that the PSI's main output - the Statement of Interdiction Principles (SOP)—includes elements that contradict with UNCLOS.

This chapter discusses the relationship of the PSI and the resolutions of the UN Security Council, whose aim is to stop the illicit transport of weapons of mass destruction (WMD) on the oceans, to the UN Convention on the Law of the Sea (UNCLOS) and to the 1921 Åland Convention. Today, all parties to the 1921 Åland Convention, as well as Russia, are participants in the PSI, and they are also parties to the UNCLOS and member States of the United Nations.

\section{The Demilitarisation of the Åland Islands}

The Åland Islands' international legal regime was confirmed in the aftermath of the First World War. The Åland Islands and its surrounding sea area was demilitarised and neutralised by the 1921 Åland Convention. In 1921, the Åland Convention stated that it is complementary to the 1856 Convention between France, Great Britain and Russia, which resulted in the demilitarisation of the Åland Islands after the Crimean War. The 1921 Åland Convention has since been supplemented by the 1940 Treaty between Finland and the Soviet Union. Following the Second World War, the 1947 Peace Treaty confirmed the status quo by declaring that 'the Åland Islands will remain demilitarised according to the present situation' Furthermore, the position of the Åland Islands was also mentioned in the EU Treaty of Accession when Finland joined the EU in $1995 .^{13}$

\footnotetext{
${ }^{12}$ Thomas (2009), p. 657.

${ }^{13}$ Convention relating to the Non-Fortification and Neutralisation of the Åland Islands, Finnish Treaty Series 1/1922, English translation available in 17 AJIL 1923, Supplement: Official Documents, pp. 1-6. Hereinafter the 1921 Åland Convention, Treaty concerning the Åland Islands between Finland and the Union of Soviet Socialist Republics, Finnish Treaty Series 24/1940. By the Armistice Agreement 19.10.1944, the bilateral treaty between Finland and the Soviet Union
} 
The location of the Aland Islands indicates that they may be of military strategic significance. A military power in control of Åland and with aggressive intentions could use the islands as a base for military operations. Sweden has always been the most active proponent of the demilitarised and neutralised status of the Aland Islands because any power controlling the Aland Islands would be able to threaten Sweden' s east coast and the capital city of Stockholm. In addition, the former Soviet Union was in favour of the demilitarisation of the Aland Islands, and a bilateral treaty between Finland and the Soviet Union was concluded on the initiative of the Soviet Union to this effect. ${ }^{14}$

Security has been the most important question in negotiations concerning the area of the Alland Islands. When Russia conquered Finland during the 1808-1809 war, the strategic situation changed in the Baltic Sea region. According to the 1809 Peace Treaty, the Torneå and Muonio rivers and the Gulf of Bothnia combined to form the Russia-Sweden border, and the Åland Islands belonged to Russia. ${ }^{15}$ This situation was worrying from a Swedish perspective because the Aland Islands were a strategic stronghold. In this sense, the situation became a serious security issue for Sweden as the Åland Islands becoming a part of Russia created new localised threats. It is easy to understand therefore that the peace negotiations following the 1808-1809 war and any other matters regarding the Alland Islands were of vital importance to Sweden. During peace negotiations, Sweden's primary goal was to retain the Åland Islands, but efforts to secure this objective failed. A second option for Sweden was the non-fortification of the islands, but this proposal was also rejected.

This notion of the non-fortification of the Aland Islands emerged again during peace negotiations following the Crimean War. Sweden had remained neutral during the war and had not taken part in the negotiations. However, Sweden used its diplomatic influence to convince Britain and France to voice concerns on its behalf. Sweden was thus presented with a new opportunity to regain the Aland Islands. If successful, the Åland Islands would belong to Sweden and the special demilitarised status of the islands would no longer be necessary. Efforts made to accomplish this, however, did not bear fruit, and instead in an effort to reach a compromise, the Åland Islands were demilitarised.

concerning the demilitarisation of the Åland Islands was re-confirmed. This meant that fortifications on the Åland Islands had to be destroyed, Reactivation of the Treaty concerning the Åland Islands between Finland and the Union of Soviet Socialist Republics, Finnish Treaty Series 9/1948, Peace Treaty with Finland, Finnish Treaty Series 20/1947: English translation available in 42 AJIL 1948, Supplement: Official Documents, pp. 203-223, Commission opinion on Finland's application for membership on 4th November 1992. The 1940 Treaty was confirmed by the 1992 Protocol between Finland and the Russian Federation.

${ }^{14}$ Hannikainen (1994), p. 615.

${ }^{15}$ The Treaty of Fredrikshamn. www.histdoc.net/history/fr/frhamn.html. Accessed 19 Jan 2016. 
The 1856 Convention is short and only covers demilitarisation. There is no clear definition in the Convention regarding the territory to which it applies. However, Article I of the Convention refers to the islands of Aland and has therefore only been applied to this specific land area. Thus, it was possible to carry out military operations in the seas surrounding the Aland Islands without infringing on the principle of demilitarisation. The 1856 Convention is also silent regarding defence arrangements permitted during times of war. During the First World War, the demilitarisation of the Aland Islands was not respected. Russia fortified the Aland Islands and used them as a base for military operations against Germany. In the late stages of the war in 1918, the Alland Islands were first occupied by Sweden and then by Germany. The fortifications were demolished in 1919 by Finland, which had emerged as a new independent State. ${ }^{16}$ In the aftermath of the First World War, the Aland Islands became an object of a territorial dispute between Finland and Sweden. ${ }^{17}$ The League of Nations settled the dispute, and the sovereignty of the Åland Islands was recognised as belonging to Finland. As a result of this settlement, the Åland Islands and their surrounding sea area were demilitarised and neutralised by the 1921 Åland Convention.

A huge threat to the demilitarised and neutralised status of the Åland Islands was posed by the outbreak of the Second World War as the Aland Islands were a key strategic focal point for belligerents. During the war, the legal status of the Aland Islands was respected, although both Germany and the Soviet Union had plans to occupy the islands. Finland, however, decided to fortify the islands. When Finland informed the parties to the 1921 Åland Convention of its military preparations, they did not express any criticism. ${ }^{18}$ Since the end of the Second World War, the Aland Islands have been spared from any further military operations.

The 1921 Aland Convention offers certain exceptions when considering a military presence within the zone during peacetime and when there is armed conflict, and the exceptions are different depending on whether the vessel is Finnish or not. Furthermore, the passage accorded to ships can be divided into two parts: namely, when passing through territorial seas and when entering internal waters. The 1921 Aland Convention limits Finnish warships and aircraft, as well as Finland's authority to regulate any access granted to foreign warships, either when entering or staying within the zone. But the Åland Convention also refers to the rules of international law and practice, in the event of the innocent passage of warships. When the Alland Convention was concluded, the international law of the sea was based on customary law, which left coastal States wide discretionary powers to determine the nature of passage. At present, the international law of the sea consists of rules that are applied from treaty law and customary international

\footnotetext{
${ }^{16}$ Hannikainen (1994), p. 617.

${ }^{17}$ O'Brien (2012).

${ }^{18}$ Hannikainen (1994), p. 618.
} 
law. Although the conventions relating to the right of innocent passage sought to codify the customary law, the very act of codification reduces a State's discretion.

The preamble to the 1921 Åland Convention says that the Convention has been made in order to guarantee peace and stability, in the sense that the Åland Islands shall never become a threat from a military perspective. The phrasing of the preamble to the Convention clearly shows that there was a common interest among States to secure the region, with a particular focus on the Åland Islands. It is understandable that the legal scope of the Convention was expanded to cover the islands' surrounding sea areas so as to prevent military activities from occurring in the future. It may also be said the geographical range of the 1921 Aland Convention is connected to various security issues and the ability of States to handle these issues within the limits of the region. The demilitarised and neutralised zone therefore exists as a consequence of localised security threats that were identified by parties to the 1921 Convention.

The 1921 Åland Convention established Åland's three-nautical- mile territorial sea, thereby separating the demilitarised and neutralised sea areas from other parts of Finland's territorial sea. A coastal State has sovereignty over its territorial sea. The right of innocent passage is the main restriction imposed by international law over any coastal State wishing to exercise sovereignty over its territorial sea. Taking the sea within the Convention, it also introduced rules of the international law of the sea to the content of the Convention. Although Article 4 prohibits all kinds of military presence in the area, there are some exceptions to this provision. These exceptions relate to Finland and its right to regulate navigation and the presence of foreign vessels in its territorial waters, which are at the same time also a demilitarised and neutralised area. During the negotiation process of the Convention, States also had to solve the question of the right of innocent passage through the demilitarised and neutralised zone.

Article 5 of the 1921 Aland Convention grants warships the right of innocent passage through areas of the Åland Islands' territorial waters that are part of the neutralised zone. However, the article makes references to international rules and usages in force that therefore sets limits to the application. The Article indicates that Finland's authority to enact rules that would prohibit the innocent passage of warships through the territorial waters of the Åland Islands is restricted. The Article is also applicable to Finnish warships, and as a result the 1921 Åland Convention restricts a coastal State's jurisdiction over its own territorial sea. The possibility of prohibiting innocent passage was never properly addressed during the 1921 Conference discussions, and only Finland had expressed its view on the matter by stating its right to prohibit innocent passage in special circumstances. ${ }^{19}$

\footnotetext{
19،... le droit d'interdire le passage inoffensive dans des circonstances spéciales” in Actes de la Conférence, p. 64.
} 


\section{An Overview of the Proliferation Security Initiative}

The Proliferation Security Initiative (PSI) arose out of the 11 September 2001 terrorist attacks and after the So San incident. The So San incident showed that the United States had no legal authority to seize the missiles of North Korean origin that were in transit to Yemen by a ship flying under the Cambodian flag. The United States lacked a clear legal authority to seize the missiles, but there was also no provision under international law prohibiting Yemen accepting the delivery of the missiles from North Korea. ${ }^{20}$ The PSI was originally proposed by the United States in 2003 in Krakow, Poland, by President Bush, who stated that the 'greatest threat to peace is the spread of nuclear, chemical and biological weapons' and announced the PSI.

'When weapons of mass destruction or their components are in transit, we must have the means and authority to seize them. So today I announce a new effort to fight proliferation called the Proliferation Security Initiative. The United States and a number of our close allies, including Poland, have begun working on new agreements to search planes and ships carrying suspect cargo and to seize illegal weapons or missile technologies. Over time, we will extend this partnership as broadly as possible to keep the world's most destructive weapons away from our shores and out of the hands of our common enemies.'21

The PSI is not a treaty but is rather a statement of intention to prevent the movement of weapons of mass destruction and related materials at ports and different maritime zones without maintaining any organisational frameworks. ${ }^{22}$ The PSI aims to complement existing international arms control arrangements. It refers to the rules of international law but not specifically to the norms of the law of the sea. ${ }^{23}$ The PSI represents new forms of international cooperation beyond international treaties and organisations.

Initially this United-States-led initiative co-opted 10 States (Poland, Australia, France, Germany, Italy, Japan, the Netherlands, Portugal, Spain and the United Kingdom). These 11 original participants are the core group of the PSI. They adopted the Statement of Interdiction Principles, which was announced on

\footnotetext{
${ }^{20}$ Ahlström (2005), p. 741, Logan (2005), p. 253, see also Garvey (2005), pp. 128-129.

${ }^{21}$ Remarks by the President to the People of Poland (2003) http://georgewbush-whitehouse. archives.gov/news/releases/2003/05/20030531-3.html.

${ }^{22}$ In the Proliferation Security Initiative meeting in London 9-10 October 2003 the participants to the meeting agreed that "the PSI was a global initiative with an inclusive mission. Successful interdiction of trafficking in WMD, their delivery systems and related materials requires the widest possible co-operation between states. Participation in the PSI, which is an activity not an organisation, should be open to any state or international body that accepts the Paris Statement of Principles and makes an effective contribution." at http://dfat.gov.au/international-relations/ security/non-proliferation-disarmament-arms-control/psi/Pages/proliferation-security-initiativelondon-9-10-october-2003-2.aspx. Klein (2011), p. 150, Jinyuan (2012), p. 97.

${ }^{23}$ See Ministry for Foreign Affairs of Finland http://formin.fi/public/default.aspx?contentid= $325890 \&$ contentlan $=2 \&$ culture $=$ en-US.
} 
4 September 2003 in Paris and which is a significant public output of the initiative. $^{24}$ The interdiction principles identify concrete actions to collectively or individually interdict shipments of WMDs, their delivery systems and related materials. ${ }^{25}$ However, the Statement of Interdiction Principles does not bind participants to the PSI legally; it is a political commitment and practical cooperation to help impede and stop the flow of WMDs, their delivery systems and related materials to and from States and non-State actors of proliferation concern. The Interdiction Principles set forth the objectives and working methods of the PSI. ${ }^{26}$

The PSI cooperation is operated by exercises and bilateral ship-boarding agreements. The aim of the PSI partnership is to establish a network that impedes and stops the illicit trafficking of WMDs and related materials, as well as their delivery systems. ${ }^{27}$ Today, 105 States have publicly endorsed the PSI, and the European Union has given its support to the cooperation. ${ }^{28}$ Finland has been a participant in the PSI since 2004. Although the PSI has no permanent institutional structure, it has an Operational Experts Group, which comprises 21 States (Australia, Argentina, Canada, Denmark, France, Germany, Greece, Italy, Japan, Republic of Korea, the Netherlands, New Zealand, Norway, Poland, Portugal, Russia, Singapore, Spain, Turkey, the United Kingdom and the United States). The group meets frequently, and its task is to take care of the planning for the initiative to ensure the PSI's effectiveness by contributing customs, law enforcement, military and other security experts and assets to interdiction exercises, hosting PSI meetings, workshop and exercises with other PSI-endorsing States. ${ }^{29}$ Through the PSI partnership, States have established a network that impedes and stops the illicit trafficking of WMDs and related material, as well as their delivery systems. ${ }^{30}$

It is clear that the international community has a negative attitude towards the proliferation of WMDs. Evidence of this is found in the number of participants in the treaties, such as the Treaty on the Non-Proliferation of Nuclear Weapons (NPT), the Biological Weapons Convention (BWC) and the Chemical Weapons Convention (CWC). However, there are number of States that are not party to the NPT Convention, e.g. North Korea. Although these conventions prohibit the proliferation, transport and sale of biological and chemical weapons, they do not grant high

\footnotetext{
${ }^{24}$ Ahlström (2005), p. 745.

${ }^{25}$ Proliferation Security Initiative: Chairman's Statement at the Third Meeting (2003).

${ }^{26}$ Ahlström (2005), p. 745, Winner (2005), p. 130.

${ }^{27}$ http://www.psi-online.info/Vertretung/psi/en/01-about-psi/0-about-us.html, Tornberg (2009), p. 140.

${ }^{28}$ China, India and Pakistan are not participants of the PSI.

${ }^{29}$ See Operational Experts Group at http://www.psi-online.info/Vertretung/psi/en/04-OperationalExperts-Group/0-operational-experts-group.html (4.2.2016). China is not a participant of the PSI, but it has a joint declaration with the European Union Joint declaration of the People's Republic of China and the European Union on Non-proliferation and Arms Control, C/04/348, Brussels, 8 December 2004, 15854/04 (Presse 348).

${ }^{30} \mathrm{http} / / /$ www.psi-online.info/Vertretung/psi/en/01-about-psi/0-about-us.html, Tornberg (2009), p. 140.
} 
seas interdictions, even inter partes. As the Legality of the Threat or Use of Nuclear Weapons Case recognises, these conventions are not sufficient evidence of State practice or opinio juris to create a legal obligation or to prohibit the use of certain weapons of mass destruction. ${ }^{31}$ The PSI was intended to establish a last means for stopping the transfers of WMDs and related materials, in case the proliferators had managed to load such material aboard a ship. The geographical scope of the initiative focused on the high seas because ships on the high seas are subject to the authority of the State whose flag they fly. ${ }^{32}$

The major problem regarding illicit trafficking is not the ready-made WMDs but components, technologies, production materials and means of delivery associated with WMDs. The problem with these items is that the majority of them are civilian as well as military end uses. The dual-use materials pose a problem because they are mostly used for peaceful purposes, and their trade is legal. The proliferation problem caused by dual-use materials is significant because 95 of the elements for WMDs are dual use. Added to this is the problem that globalisation and technological advancement and the dissemination and accessibility of knowledge and technology necessary to acquire WMD capabilities have increased exponentially since the 1990s. This development has not only increased the ability of States to obtain WMDs but has also enabled non-State actors to obtain them. Thereby, the main concern of the PSI is to prevent States and non-State actors of proliferation concern from acquiring the materials to build WMDs. ${ }^{33}$ However, States have to bear in mind that especially in the case of nuclear materials, the legal transfer of nuclear materials is also an issue. Regarding the right of innocent passage, Article 23 of UNCLOS establishes requirements ${ }^{34}$ for the trafficking of foreign nuclearpowered ships and ships carrying nuclear or other inherently dangerous or noxious substances. Thus, government transportation is out of the scope of the PSI. It applies only to commercial transportation. Consequently, any unlawful activities undertaken by warships in the exercise of their official duties will be governed by rules of international law. ${ }^{35}$ According to UNCLOS, warships are required to comply with the laws and regulations of the coastal State concerning passage through the territorial sea. If a foreign warship disregards a request for compliance made to it, the coastal State may require it to leave the territorial sea immediately. ${ }^{36}$

\footnotetext{
${ }^{31}$ Legality of the Use by a State of Nuclear Weapons in Armed Conflict, Advisory Opinion, I. C. J. Reports 1996, pp. 66, 226.

${ }^{32}$ Durkalec (2012), p. 2, Ahlström (2005), p. 744, Byers (2004), p. 527.

${ }^{33} \mathrm{http} / / / w w w . s t a t e . g o v / t / i s n / c 10390 . h t m$, Fidler (2003), Prosser and Scoville (2004), Beck (2004), p. 16, Logan (2005), p. 255, Jimenez Kwast (2007), pp. 164-167.

${ }^{34}$ Article 23 requires that foreign nuclear-powered ships and ships carrying nuclear or other inherently dangerous or noxious substances provide certain documents upon request and observe special precautionary measures established for them according to international agreements when they exercise their right of innocent passage.

${ }^{35}$ Lehto (2008), p. 57.

${ }^{36} \mathrm{UNCLOS}$ art. 30.
} 
Over $90 \%$ of international trade is transported by sea; therefore, the marine transport of WMDs and related materials is the core concern of the PSI. Today, maritime shipping is fast and cost-effective, owing to the use of standardised containers that can be directly transferred to and from ground networks at the ports. The effectiveness of the transportation system in ordinary commercial shipping increases the possibility that WMD-related materials are trafficked undetected. At sea, the boarding and inspection of big containerships requires well-resourced and trained forces and is still difficult and dangerous. Furthermore, any kind of delay in shipping results in increased costs. ${ }^{37}$ Taking into consideration that the illicit shipment of WMD-related materials is not frequent, the costs of the implementation of the PSI by stopping and searching numerous ships that are not causing any threat would be unreasonable for commercial shipping. ${ }^{38}$

The PSI is an effort to cover the weaknesses of the international non-proliferation regime, and that is also the purpose of Security Council Resolution 1540 (2004) adopted under Chapter VII UN Charter. The resolution endeavours to fill gaps in international non-proliferation efforts by obliging States to refrain from providing any form of support to non-State actors that attempt to develop, acquire, manufacture, possess, transport, transfer or use nuclear, chemical or biological weapons and their means of delivery and encourages States to take effective measures to conform their relevant obligations and responsibilities. ${ }^{39}$ However, the resolution does not authorise interdiction. Regarding criminal jurisdiction, the illicit trafficking of WMDs and related materials is not classified as universal crime, and thus it is not subject to universal jurisdiction.

The PSI participants' readiness to conduct interdiction operations is developed by exercises. These exercises have made it possible for different authorities of the participants in the PSI such as armed forces, customs, police and intelligence to meet and create connections with each other. Today, the PSI is increasingly focused on commercial trade in dual-use materials, which has also made the exercises more civilian oriented. Although the exercises involve more civilian law enforcement authorities, most of the exercises still have a strong military aspect. ${ }^{40}$

\subsection{Scope of the UNSC Resolutions}

The Security Council has linked the proliferation of nuclear, chemical and biological weapons, as well as their means of delivery, with the notion of a threat to

\footnotetext{
${ }^{37}$ Jimenez Kwast (2007), p. 167 see also fn. 24, Kraska (2009), p. 123.

${ }^{38}$ Logan (2005), p. 259.

${ }^{39}$ UN Security Council Resolution 1540 (2004), Jimenez Kwast (2007), p. 169, see also Resolutions 1673 (2006), 1805 (2008) and 1977(2011), extending the mandate of the Committee to April 252021.

${ }^{40}$ Durkalec (2012), pp. $15-16$.
} 
international peace and security with Resolution 1540 of 28 April 2004 adopted under Chapter VII of the Charter and the others that followed it. The resolutions also define the means of delivery to cover missiles, rockets and other unmanned systems capable of delivering nuclear, chemical or biological weapons that are specially designed for such use. ${ }^{41}$

The resolutions state that the proliferation of WMDs, as well as their means of delivery, constitutes a threat to international peace and security and oblige States to refrain from providing any form of support to non-State actors that attempt to develop, acquire, manufacture, possess, transport, transfer or use WMDs and related materials and to adopt and enforce appropriate effective laws that prohibit any non-State actor to manufacture, acquire, possess, develop, transport, transfer or use these materials. Furthermore, the resolution required States to take and enforce effective measures to establish domestic controls to prevent the proliferation, including (a) accountability, (b) physical protection, (c) border controls and law enforcement efforts and (d) national export and trans-shipment controls. ${ }^{42}$ Security Council Resolution 1540 as well as further resolutions do not specifically authorise the non-flag States to board ships and to seize WMD-related cargo or provide any other enforcement authority. ${ }^{43}$ Interdiction was not included in the resolution because of China's opposition to the matter, and thus the resolution only refers to international cooperation to prevent illicit trafficking. ${ }^{44}$

The main rule in international law of the sea recognises the exclusive jurisdiction of a flag State on the high seas. Some provisions of UNCLOS are exceptions to this main rule. The exceptions are related universal crimes occurring on the high seas. Today, State practice and treaties after over a decade of adoption of the PSI and UNSC Resolutions have not amended the flag State's exclusive jurisdiction over its ships, although the popularity of the PSI might indicate that there has emerged a norm of customary international law against proliferation allowing States to take certain actions to prevent it. ${ }^{45}$ However, during the negotiations for the resolution on non-proliferation of weapons of mass destruction, a representative of the United Kingdom stated that the resolution does not 'authorize enforcement action against States or against non-State actors in the territory of another country. The draft resolution makes clear that it will be the Council that will monitor its implementation. Any enforcement action would require a new Council decision.' The representative of the United States also stated that the resolution is 'not about enforcement'. ${ }^{46}$

\footnotetext{
${ }^{41}$ UN Security Council Resolutions 1540(2004), 1810(2008), 1977(2011).

${ }^{42}$ UN Security Council Resolution 1540 (2004), Durkalec (2012), p. 13.

${ }^{43}$ Rayfuse (2005), p. 198, Logan (2005), p. 270, Durkalec (2012), p. 13.

${ }^{44}$ Winner (2005), p. 136.

${ }^{45}$ Logan (2005), p. 271.

${ }^{46}$ UN Security Council meeting of April 22 S/PV.4950 (2004), p. 12, 17. The Council has adopted enforcement actions against Iran (Resolution 1929 (2010)) and North Korea (Resolution 1874 (2009)). These Resolutions 'call on all states to inspect all cargo to and from Iran and North Korea
} 
UN Security Council Resolutions are a step towards a universal global non-proliferation regime. Today, they supplement existing non-proliferation and disarmament laws and regulations, but the resolutions do not grant any new authority or jurisdiction to States. ${ }^{47}$

\section{Legal Problems with the PSI and the Right of Innocent Passage}

Security Council Resolutions, the 2005 SUA Protocol being the first international convention recognising the trafficking of WMDs and related materials as illegal, and the right of self-defence do not provide any enforcement power, or if they do, the power is limited in certain circumstances on the high seas where a flag State has exclusive jurisdiction over the ship and crew. ${ }^{48}$ Thus, the use of national military and law enforcement power is regulated by the rules of the law of the sea. Even though the freedom of navigation, one of the oldest principles of the customary international law, is limited in certain circumstances, even on the high seas, where a warship has a right to board vessels, regarding the illicit trafficking of WMDs and related materials, the problem is that the illicit trafficking of WMDs and related materials is not universally condemned in the same terms in the law of the sea as the slave trade. ${ }^{49}$ On the territorial seas, the principle of freedom of navigation is exercised through the concept of the right of innocent passage. Regarding the illicit trafficking of WMDs and related materials, it would be wrong if the right of ships to exercise freedom of navigation on the high seas were to be more limited than the right to innocent passage within a coastal State's territorial waters.

The United Nations Convention on the Law of the Sea authorises the boarding of a foreign ship on the high seas in cases of piracy, slave trade, unauthorised broadcasting or when a ship is stateless. ${ }^{50}$ Foreign warships or coast guard authorities may interdict and search a ship only in the aforementioned cases. A coastal State has power under international law to stop and seize cargo on its internal waters and territorial sea, except when a foreign ship is exercising the right of innocent passage. The 2005 SUA Protocol criminalised and created new enforcement procedures to prevent maritime terrorism and the use of ships by terrorists and for

\footnotetext{
that is in their territory, including seaports and airports, if there are "reasonable grounds" to believe the cargo contains items of which the supply, sale, transfer or export is prohibited. Both resolutions also call on states to cooperate in inspections and, more significantly, they authorize all UN members to seize and dispose of prohibited cargo'. Durkalec (2012), p. 13. The Resolution 1929 (2010) was terminated by the Resolution 2231(2015) see http://www.un.org/en/sc/2231/.

${ }^{47}$ Allen (2007), p. 59.

${ }^{48}$ Jinyuan (2012), p. 98, Dixon (2006), p. 23, Durkalec (2012), p. 14.

${ }^{49}$ Cirincione and Williams (2005).

${ }^{50} \mathrm{UNCLOS}$ art. 110.
} 
terrorist purposes. Article 8bis created a new procedure for boarding a ship on the high seas, which is suspected of being involved in offences under the SUA Convention. ${ }^{51}$ However, the Convention does not contain any change for the flag State's exclusive jurisdiction on the high seas; thus, a State party to the Convention has to ask the flag State's authorisation to board and to take appropriate measures.

The UN Law of the Sea Convention does not directly speak about security issues; although some provisions regulate warships, they do not deal with naval warfare, disarmament, demilitarisation or denuclearisation. The lack of discussions of military operations in the UN Law of the Sea Conference was not accidental; they were deliberately left out of the discussions. ${ }^{52}$ The Convention refers to security in the context of the right of innocent passage. ${ }^{53}$ The indirect references to the security issues indicate that the Convention's intention is to regulate the uses of the seas in times of peace. A coastal State may temporarily suspend the right of innocent passage if it deems such suspension essential for the protection of its security (Article 25(3)). Article 21 grants a coastal State the possibility to regulate the passage of ships exercising their right of innocent passage; however, those laws and regulations may focus on the safety of navigation and protection of the marine environment, not security matters.

\section{Interdictions by Participants in Their Territorial Sea}

\subsection{Sovereignty and Jurisdiction of Coastal States}

Aside from territorial sea claims, States are primarily concerned about the rights of access and resource exploitation within their territorial waters. The most important topics concerning legislative jurisdiction have been navigation, customs, fishing, sanitation and security. Oceans have always served as the most convenient highway for launching attacks, and because of this, coastal State security interests are grounded by a crucial understanding that territorial seas provide important routes to follow when reaching shores. Coastal State claims to authority over territorial sea areas are commonly described as an assertion of sovereignty over a part of coastal State's land territory. ${ }^{54}$

Sovereignty includes territorial sea claims made by States as they seek to control access to their waters. In aiming to secure comprehensive and continuous authority to deny passage through their territorial seas, the focus of coastal States has mainly centred upon the concept of innocent passage. Moreover, States have sought a

\footnotetext{
${ }^{51}$ Bergin (2005), pp. 89-90.

${ }^{52}$ O’Connell (1984), p. 825, Hakapää (1988), pp. 69-70, Vukas (2004), pp. 4-5, Rayfuse (2005), p. 189.

${ }^{53}$ UNCLOS art. 19.

${ }^{54}$ McDougal and Burke (1987), p. 179.
} 
number of claims that have included occasional exclusive competence to deny passage in regard to specific cases, a right to prescribe policy for territorial sea cases, a right to prescribe and apply policies to solve problems aboard vessels and a right to the exclusive appropriation of resources. ${ }^{55}$

Sovereignty over territorial sea areas grants coastal States the following rights:

- Coastal States have an exclusive right to fish and to exploit the resources of the seabed and subsoil.

- They have exclusive enjoyment of the air space above the territorial sea area as foreign aircraft does not enjoy the same rights of innocent passage as foreign vessels do.

- A coastal State has an exclusive right to transport goods and passengers from one part of its territory to another part.

- During times of war when a coastal State is neutral, belligerent States are not allowed to engage in combat, or capture merchant vessels, within the coastal State's territorial sea.

- Foreign vessels must obey regulations concerning navigation, health, customs duties and immigration that are enacted by a coastal State. ${ }^{56}$

In addition to these rights, a coastal State has both civil and criminal jurisdiction over merchant vessels exercising the right of innocent passage, as well as persons on board such vessels. ${ }^{57}$ Regarding warships, however, a coastal State does not have this kind of jurisdiction and may only demand that the warship leave its territorial sea if it does not comply with persistent requests to adhere to coastal State regulations. ${ }^{58}$

The Statement of Interdiction Principles says that the PSI activities will not violate international law. However, subparagraph 4 (d) of the Statement of Interdiction Principles calls participants to take appropriate actions to do the following:

(1) stop and/or search in their internal waters, territorial seas or contiguous zones (when declared) vessels that are reasonably suspected of carrying such cargoes to or from States or non-State actors of proliferation concern and to seize such cargoes that are identified; and

(2) to enforce conditions on vessels entering or leaving their ports, internal waters or territorial seas that are reasonably suspected of carrying such cargoes, such as requiring that such vessels be subject to boarding, search and seizure of such cargoes prior to entry.

\footnotetext{
${ }^{55}$ McDougal and Burke (1987), p. 179.

${ }^{56}$ UNCLOS arts. 2, 19, 21, Convention (XIII) concerning the Rights and Duties of Neutral Powers in Naval War, adopted on 18 October 1907 and entered into force on 26 January 1910 art. 1, Malanczuk (1997), pp. 177-178.

${ }^{57}$ TSC arts. 19, 20, UNCLOS arts. 27, 28, Malanczuk (1997), p. 178.

${ }^{58} \mathrm{TSC}$ art 23, UNLOSC art. 30.
} 
The requirement in subparagraph 4 (d) (1) is problematic because although coastal States have sovereignty over their territorial seas, it is limited by the right of innocent passage of foreign vessels. ${ }^{59}$ A coastal State may not hamper the passage of foreign ships through the State's territorial sea if not being prejudicial to the peace, good order or security of the coastal State. ${ }^{60}$ Instead, if the interdiction of a ship under a flag different from the coastal State takes place in the internal waters by the coastal State authorities, the act is in accordance with the law of the sea. $^{61}$

However, in the territorial sea, the right of innocent passage makes the situation complicated. Regarding the coastal State's legislative competences, the 1982 UN Law of the Sea Convention contains specific provisions relating to innocent passage. According to Article 21 (1):

[a] a coastal State may adopt laws and regulations, in conformity with the provisions of this Convention and other rules of international law, relating to innocent passage through the territorial sea, in respect of all or any of the following:

(a) the safety of navigation and the regulation of maritime traffic;

(b) the protection of navigational aids and facilities and other facilities or installations;

(c) the protection of cables and pipelines;

(d) the conservation of the living resources of the sea;

(e) the prevention of infringement of the fisheries laws and regulations of the coastal State;

(f) the preservation of the environment of the coastal State and the prevention, reduction and control of pollution thereof;

(g) marine scientific research and hydrographic surveys;

(h) the prevention of infringement of the customs, fiscal, immigration or sanitary laws and regulations of the coastal State.

In addition, coastal States must give due publicity to their laws. Moreover, such laws may not affect the design, construction, manning or equipment of foreign vessels unless they conform to generally accepted international standards. ${ }^{62}$

Article 21 limits a coastal State's prior legislative competences and therefore provides a jurisdictional compromise between coastal State and flag State interests. Instead, the article grants coastal States certain legislative competences but eliminates the risk of divergent design, construction, manning and equipment standards that might be hard to accommodate when vessels set out on voyage. ${ }^{63}$ Foreign vessels have to comply with coastal State laws that are enacted analogously with the Convention. ${ }^{64}$ Furthermore, in accordance with Article 21(4), '[f]oreign ships

\footnotetext{
${ }^{59} \mathrm{UNCLOS}$ art. 17.

${ }^{60}$ Klein (2011), p. 200.

${ }^{61}$ Wolfrum (2009), p. 90.

${ }^{62}$ Yearbook of International Law Commission (1956), p. 274, Churchill and Lowe (1999), p. 94.

${ }^{63}$ Churchill and Lowe (1999), p. 94, Harrison (2013), p. 170.

${ }^{64}$ Churchill and Lowe 1999, pp. 94-95. According to Article 22 a coastal State is not allowed to dismiss recommendations made by the IMO, a competent international organisation, when ordering sea lanes. Harrison (2013) argues, however, that the IMO has only a recommendatory role in this situation (p. 180).
} 
exercising the right of innocent passage through the territorial sea shall comply with all such laws and regulations and all generally accepted international regulations relating to the prevention of collisions at sea'. ${ }^{65}$ It is irrelevant whether a flag or coastal State is party to conventions containing such regulations. ${ }^{66}$

Article 21 contains an exhaustive list that clearly restricts the matters that a coastal State may regulate. Thus, a coastal State cannot draw any authorisation from Article 21 to implement the PSI unless the coastal State is the destination of the illegal shipment of WMD materials.

\subsection{The Right of Innocent Passage}

The 1958 Territorial Sea Convention determines that passage is innocent if it is not prejudicial to the peace, good order or security of the coastal State. The Convention mentioned two activities that were dissociated from the character of innocence. The passage of foreign fishing vessels was not considered innocent if vessels did not observe coastal State laws and regulations. Laws and regulations made and published by coastal States had generally been created with the intention of preventing vessels from fishing in territorial sea areas. The second exception to the rule was that submarines had to navigate on the surface and display their national flag. Otherwise, legal competence was left to the broad jurisdiction of the coastal States in question when determining whether passage was innocent or not. $^{67}$

The situation concerning the concept of innocence changed in 1982 after the UN Law of the Sea Convention was adopted. UNCLOS includes more specific definitions concerning innocent passage. In Article 19(2), a list of activities that are considered prejudicial to the peace, good order or security of the coastal State are mentioned as follows:

1. Passage is innocent so long as it is not prejudicial to the peace, good order or security of the coastal State. Such passage shall take place in conformity with this Convention and with other rules of international law.

2. Passage of a foreign ship shall be considered to be prejudicial to the peace, good order or security of the coastal State if in the territorial sea it engages in any of the following activities:

(a) any threat or use of force against the sovereignty, territorial integrity or political independence of the coastal State, or in any other manner in violation of the principles of international law embodied in the Charter of the United Nations;

(b) any exercise or practice with weapons of any kind;

(c) any act aimed at collecting information to the prejudice of the defence or security of the coastal State;

\footnotetext{
${ }^{65}$ For example, Convention on the International Regulations for Preventing Collisions at Sea, London, 20th October 1972, which entered into force on 15th July 1977, 1050 UNTS 16.

${ }^{66}$ Churchill and Lowe (1999), p. 95.

${ }^{67}$ TSC art. 14.
} 
(d) any act of propaganda aimed at affecting the defence or security of the coastal State;

(e) the launching, landing or taking on board of any aircraft;

(f) the launching, landing or taking on board of any military device;

(g) the loading or unloading of any commodity, currency or person contrary to the customs, fiscal, immigration or sanitary laws and regulations of the coastal State;

(h) any act of wilful and serious pollution contrary to this Convention;

(i) any fishing activities;

(j) the carrying out of research or survey activities;

(k) any act aimed at interfering with any systems of communication or any other facilities or installations of the coastal State;

(1) any other activity not having a direct bearing on passage.

However, the list is not a comprehensive one because the last item forbids any other activity that is not actually relevant to passage. Nonetheless, any activity that has no direct bearing on passage will not automatically render passage non-innocent. ${ }^{68}$

The list focuses on vessels' activities and therefore suggests that the nature of a vessel is not sufficient grounds for considering passage non-innocent. In addition, Article 23 goes further and sets obligations for foreign nuclear-powered vessels and vessels carrying nuclear or other inherently dangerous or noxious substances when they are exercising the right of innocent passage through the territorial sea. ${ }^{69}$ Consequently, UNCLOS does not prohibit the shipment of WMDs or related materials. ${ }^{70}$ Article 23 of the Convention only obliges foreign nuclear-powered vessels and vessels carrying nuclear or other inherently dangerous or noxious substances to carry certain documents and to observe special precautionary measures established for such vessels by international agreements when they are exercising the right of innocent passage through territorial seas. ${ }^{71}$ Article 23 clearly limits the authority of coastal States as they take into account certain issues related to nuclear-powered vessels and vessels carrying nuclear materials when a decision must be made in relation to whether passage is deemed to be innocent or not. This provision indicates that the nature of the vessel or its cargo does not influence the right of innocent passage as long as it carries with it the appropriate documents and conforms to precautionary measures established by international law. ${ }^{72}$ However, as the So San case ${ }^{73}$ shows, it is highly probable that a ship involved in the illicit

\footnotetext{
${ }^{68}$ Pharand (1977), p. 77, Churchill and Lowe (1999), p. 84.

${ }^{69}$ Art. 23: Foreign nuclear-powered ships and ships carrying nuclear or other inherently dangerous or noxious substances shall, when exercising the right of innocent passage through the territorial sea, carry documents and observe special precautionary measures established for such ships by international agreements.

${ }^{70}$ Rayfuse (2005), p. 190. United States required Article 23 to the Convention.

${ }^{71}$ International agreements, such as the International Convention for the Safety of Life at Sea (SOLAS) and its Annex, as well as IMO recommended codes regarding the construction and equipment of ships carrying dangerous liquid chemicals or liquefied gases in bulk, Nordquist et al. (1993), p. 220.

${ }^{72}$ See International Association of Lawyers Against Nuclear Arms Aotearoa New Zealand Branch http://lcnp.org/disarmament/nwfz/submission\%20on\%20NWF2.htm.

${ }^{73}$ The freighter So San was transporting according to ship's manifest 2000 pounds of concrete, however, it was also transporting missile parts and an unknown chemical, see Joyner (2005), p. 2.
} 
trafficking of WMD materials will not carry documents required by Article 23, nor will it observe precautionary measures. But the coastal State has the right of non-flag enforcement only if a ship carrying WMDs or related materials engages such activities that render its passage non-innocent. ${ }^{74}$ Writers have raised the question of whether the illicit trafficking of WMDs and related materials through the territorial seas can be deemed non-innocent. ${ }^{75}$

Some writers have suggested that the mere passage of a ship carrying illicitly WMDs is a violation of the right of innocent passage. Lehrman states that although the list in Article 19(2) does not explicitly refer to trafficking in WMDs or related materials as prejudicial to the peace, it does not foreclose such an interpretation. ${ }^{76}$ Kaye argues that 'Clearly the delivery of WMD to terrorists may well be highly prejudicial to the peace, good order and security of a coastal State, an argument could be made that such a passage is therefore not innocent, and the restrictions on coastal State authority over the passing vessel are removed'. ${ }^{77}$ Further, Churchill and Lowe claim that activities seen as posing a threat of force affect third States, as well as coastal States. Because a coastal State's security is seen by Churchill and Lowe as being indirectly linked to a third State's welfare, they also believe that there is no need for links to other legal instruments, such as a mutual defence treaty, when aiming to render threats as incompatible with innocent passage. Thus, paragraph 2 may be interpreted in such a way as to allow coastal States to act on the impression that a third State's security is at stake. ${ }^{78}$ Further, Joyner holds the view that the wording of Article 19 (2)(a) is wide enough to include a threat of force against a third State. ${ }^{79}$

Ronzitti has an opposing view, arguing that a ship entering territorial sea at one point from the high seas and leaving at another without any intention to enter internal waters or stop at any port does not violate the right of innocent passage. ${ }^{80}$ Similarly, Garvey argues that the mere shipment of WMD materials does not constitute a threat to the coastal State. ${ }^{81}$ In addition, Logan states that the shipment of WMD materials does not fit within any of the exceptions listed in Article 19. Logan believes that it would be difficult, first, to prove that the shipping of WMD and related materials constituted a threat of force against the coastal State because 95 percent of the materials for WMDs are dual use in nature. Second, it would also be difficult to prove that the shipping of WMD materials threatened the coastal State's sovereignty, territorial integrity or political independence and that the WMD materials were going to be used against that particular State. Third, a

\footnotetext{
${ }^{74}$ Rayfuse (2005), p. 190.

${ }^{75}$ Ronzitti (1990), p. 5, Churchill and Lowe (1999), p. 85, Lehrman (2004), p. 232, Garvey (2005), p. 131, Joyner (2005), p. 529, Logan 2005), p. 259, Kaye (2006), pp. 147-148.

${ }^{76}$ Lehrman (2004), p. 232.

${ }^{77}$ Kaye (2006), pp. 147-148.

${ }^{78}$ Churchill and Lowe (1999), p. 85.

${ }^{79}$ Joyner (2005), p. 529.

${ }^{80}$ Ronzitti (1990), p. 5.

${ }^{81}$ Garvey (2005), p. 131.
} 
violation of the UN Charter requires that the threat or use of force is made in the territorial sea, and thus a coastal State cannot rely on the future use of the WMDs because the use is unlikely to take place in the territorial sea. ${ }^{82}$

The provisions of the 1982 UN Law of the Sea Convention are more detailed than the simple definitions provided in the 1958 Territorial Sea Convention. It seems obvious that the aim of the 1982 UN Law of the Sea Convention was to produce a more objective definition that would leave coastal States less scope for interpretation, as well as less potential to abuse their rights when suspending non-innocent passage. Within the 1982 UN Law of the Sea Convention text, there are particular references made to activities. Therefore, a vessel's presence or passage alone cannot be interpreted as prejudicial to coastal State interests if the vessel does not engage in some specific actions. Thus, the formulation of the provision regulating innocent passage would narrow the scope of the right of innocent passage by adding the illicit trafficking of WMDs and related materials and their delivery systems to the activities that are prejudicial to the peace, good order or security of the coastal State.

The United States and the former Soviet Union signed the bilateral Treaty on the Uniform Interpretation of Norms of International Law Governing Innocent Passage in $1989 .{ }^{83}$ Paragraph 3 of this Treaty states the following:

Article 19 of the Convention of 1982 sets out in paragraph 2 an exhaustive list of activities that would render passage innocent. A ship passing through the territorial sea that does not engage in any of those activities is in innocent passage.

The Uniform Interpretation does not leave an understanding of innocence open to interpretation. Both States are notable maritime powers,${ }^{84}$ and their interpretation was influential at the time of the agreement. It is noteworthy that these States referred to the 1982 UN Law of the Sea Convention. Their common objectives were obviously to contribute to State practice and to promote their own interpretation in the future evolution of customary international law. The Uniform Interpretation was signed on September 1989, at which time the former Soviet Union had signed the 1982 UN Law of the Sea Convention, but the United States had not. However, the former Soviet Union had not ratified the 1982 Convention, ${ }^{85}$ and the Convention had not entered into force. The Uniform Interpretation made between the two States is binding upon the two States parties to it but not applicable to third party States. However, the provisions included in the bilateral treaty may become binding on third party States if they become norms of customary international law. ${ }^{86}$ The

\footnotetext{
${ }^{82} \operatorname{Logan}(2005)$, p. 259.

${ }^{83}$ LOSB (1989), p. 12.

${ }^{84}$ Nowadays Russia, after the disintegration of the Soviet Union.

${ }^{85}$ The Russian Federation ratified the United Nations Convention on the Law of the Sea on 12th February 1997. The United States signed the Convention on 29th July 1994 and on 7th October 1994 President Clinton transmitted to the Senate the United Nations Convention on the Law of the Sea. Treaty Document 103-39.

${ }^{86}$ Churchill and Lowe (1999), p. 86. The United Nations Convention on the Law of the Sea entered into force 16.11.1994.
} 
restrictive interpretation of the article was created with the best interests of maritime powers in mind because it limits the discretion of a coastal State and thus benefits foreign navies navigating the world's oceans. Although the United States and the Soviet Union considered the list a comprehensive one, in fact it included the phrase 'any other activity not having a direct bearing on passage', which left some scope for further interpretation by coastal States with regard to the nature of passage. ${ }^{87}$ At the time they did not see non-State actors as possible users of WMDs, and therefore there is a strong possibility that the Uniform Interpretation is not intended to restrict the interpretation of Article 19(2) in the case of the illicit trafficking of WMDs and related materials and their devices.

Writers' differing opinions regarding the activity making the passage non-innocent illustrate that there is a need to discuss the balance of new modes of threats to coastal States and maritime security caused by non-State actors and the freedom of navigation for merchant vessels that has been historically linked to world interests.

However, although the list is considered non-exhaustive, any activity that has no direct bearing on passage will not automatically render passage non-innocent. Instead, coastal States have to provide evidence of activities that are deemed prejudicial to coastal States' peace, good order or security. ${ }^{88}$ A coastal State has to acquire solid intelligence proving that WMD materials were being shipped on the territorial sea.

\subsection{The Territorial Waters of the Aland Islands}

The essential question to ask in relation to the innocent passage of ships illegally carrying WMD and related materials through the territorial waters of the Aland Islands is whether there is sufficient scope available to consider passage non-innocent on the grounds that passage compromises the principles of demilitarisation and neutralisation. Governmental transportation, such as naval warships, is out of the scope of the PSI as it applies only to commercial transportation. Consequently, any unlawful activities undertaken by warships in the exercise of their official duties will be governed by rules of international law. ${ }^{89}$ Article 4 (1) of the 1921 Alland Convention says that 'Except as provided in Article 7, no military, naval or air force of any Power shall enter or remain in the zone described in Article 2; the manufacture, import, transport and re-export of arms and implements of war in this zone are strictly forbidden'. However, the 1921 Aland Convention particularly mentions warships that have a right of innocent passage

\footnotetext{
${ }^{87}$ Hakapää and Molenaar (1999), p. 132.

${ }^{88}$ Churchill and Lowe (1999), p. 84.

${ }^{89}$ Lehto (2008), s. 57.
} 
according to regulations established by international law. Thus, the right of innocent passage of warships is firmly embedded in a separate article, Article $5 .^{90}$ This indicates that the intention of parties to the Convention could have been to exclude any evaluation of the innocent passage of warships from being based on concepts of demilitarisation and neutralisation. With this in mind, then, it seems that Finland is not authorised to declare passage non-innocent on the ground that warships prejudice the peace, good order or security of the Islands because of its demilitarised and neutralised status.

The right of innocent passage of merchant ships has its origin in the customary international law and is codified in the 1958 Territorial Sea Convention and, today, in the UN Convention on the Law of the Sea. Thus, although the 1921 Aland Convention does not mention merchant ships, it is unlikely that the right of innocent passage of merchant ships as such was meant to be restricted. Furthermore, this grey area in the Convention's text means that an interpretation of innocent passage must be primarily founded on the rules of international law and practice. Regarding the Finnish national legislation, there are no detailed accounts of what constitutes an act of non-innocent passage. ${ }^{91}$ Under the Finnish Territorial Surveillance Act, the entry, stay and departure of vessels to and from Finnish territorial seas is stated to be governed by any relevant separate provisions or international treaties binding on Finland. ${ }^{92}$ Hence, any evaluation of the nature of passage, whether innocent or not, rests on the interpretation of UNCLOS.

According to the preamble of the 1921 Åland Convention, it was concluded that the objective of the Convention was to reduce the islands' potential as a military threat. The purpose of the Convention was to protect the coastal States of the Baltic Sea region and not just Finland. Security was an important motive when States signed the Åland Convention. The general protection of the region was achieved by demilitarising and neutralising the land areas and surrounding waters. Thus, demilitarisation and neutralisation ensured the safety of the region by keeping the area free from military deployments or operations. When discussing the territorial waters of the Åland Islands, therefore, one should always bear in mind the interests of the wider group of countries and not just the principal coastal State involved. Therefore, in the case that the illicit trafficking of WMDs and related materials will be used against a party to the 1921 Alland Convention, the shipment poses a threat of force although affecting the third State, the shipment is not in accordance with the Convention's aim and purpose. The demilitarised sea area is established to guarantee peace and stability in the sense that the Aland Islands shall never become a

\footnotetext{
${ }^{90}$ Article 5 says: "The prohibition to send warships into the zone described in Article 2 or to station them there shall not prejudice the freedom of innocent passage through the territorial waters. Such passage shall continue to be governed by the international rules and usages in force."

${ }^{91}$ Innocent passage is defined in the Finnish Territorial Surveillance Act (755/2000) Section 2 and includes a specific reference to the 1982 UN Law of the Sea Convention.

${ }^{92}$ The Finnish Territorial Surveillance Act, the Finnish Collection of Decrees 178/1938, 755/2000 Section 3.
} 
threat from a military perspective. However, today, non-State actors, for example an international terrorist network, can also get in their hands on a nuclear device, which could constitute a serious and imminent danger to the parties to the 1921 Åland Convention. In this kind of situation, if Finnish authorities had acquired solid intelligence that proved the illicit trafficking of a nuclear device, even a temporary presence of illicit trafficking of nuclear devices within the demilitarised and neutralised zone would become an obvious threat. Therefore, today, this sort of passage does not seem to conform to the 1921 Åland Convention.

\subsection{Article 25 of UNCLOS}

According to Article 25 of the 1982 UN Law of the Sea Convention, a coastal State may take necessary steps in its territorial sea to prevent passage that is not innocent. The article mentions the concept of 'innocence', which seems to be the main criterion. Passage is another prerequisite that a vessel must fulfil before innocence can be evaluated. The 1982 UN Law of the Sea Convention also defines the concept of 'passage' but is silent about vessels that do not fulfil the Convention's requirements of passage. Churchill and Lowe claim that the right to exclude passage exists in customary international law. Vessels hovering around territorial seas could be deemed non-innocent and may therefore justifiably be excluded from coastal States' waters. As passage is directly linked to the concept of innocence, any violation of passage will automatically be a violation of innocence. The right of innocent passage applies to vessels as they undertake their voyages through the territorial sea of a foreign coastal State. If a vessel were to lose the right to innocent passage, it would then be subject to coastal State jurisdiction, which could possibly lead to an arrest. ${ }^{93}$

Innocent passage may be suspended temporarily for two reasons in particular. Article 25(2) says that

[i]n the case of ships proceeding to internal waters or a call at a port facility outside internal waters, the coastal State also has the right to take the necessary steps to prevent any breach of the conditions to which admission of those ships to internal waters or such a call is subject.

Hakapää and Molenaar have also remarked on this kind of interference, as they claim that the prevention of innocent passage could take place when a coastal State suspects a foreign vessel of smuggling alcohol or drugs into its territorial waters. ${ }^{94}$ Paragraph 2 might imply that the coastal State could stop inbound ships that it suspected of illicit trafficking of WMD or related materials and their devices. ${ }^{95}$ The

\footnotetext{
${ }^{93}$ Churchill and Lowe (1999), p. 87.

${ }^{94}$ Hakapää and Molenaar (1999), p. 133.

${ }^{95} \operatorname{Logan}$ (2005), p. 261.
} 
other reason for suspending innocent passage arises when a coastal State believes that suspension is completely necessary for the protection of itself and its interests. ${ }^{96}$ A coastal State has a right to suspend passage through its territorial sea and may determine whether the passage of a vessel prejudices its security. It is noteworthy that the right temporarily to suspend innocent passage covers merchant vessels and warships. Coastal States may exercise this right to exclude foreign vessels from restricted areas, but the suspension has to be non-discriminatory and published before becoming effective.

The illicit trafficking of WMDs and related materials and their devices does not seem to fit within the scope of Article 25(3) because its suspension may not be discriminatory and the PSI interdiction is aimed at a specific ship or actors of concern. Furthermore, the PSI interdiction operations have to occur in a specific area. However, Article 25(1) may establish the legal basis for the PSI interdictions if the illicit trafficking of WMDs and related materials makes the passage non-innocent according to Article 19(2).

According to Article 25(1) of UNCLOS, coastal States are allowed to take necessary steps to prevent non-innocent passage from taking place in their territorial seas. What are, then, 'the necessary steps' that a coastal State may take after the passage is rendered non-innocent? The ship in non-innocent passage is subject to full coastal State authority, and 'the coastal State may use any necessary force, proportionate to the circumstances, to require a delinquent vessel to leave its territorial sea'. ${ }^{97}$

\subsection{Criminal Jurisdiction in the Territorial Sea}

A coastal State has both civil and criminal jurisdiction over merchant vessels exercising the right of innocent passage, as well as persons on board such vessels. ${ }^{98}$ However, a coastal State may exercise criminal jurisdiction over foreign ships in its territorial sea only according to Article 27 of UNCLOS. ${ }^{99}$ Article 27 of UNCLOS states the following:

1. The criminal jurisdiction of the coastal State should not be exercised on board a foreign ship passing through the territorial sea to arrest any person or to conduct any investigation in connection with any crime committed on board the ship during its passage, save only in the following cases:

(a) if the consequences of the crime extend to the coastal State;

(b) if the crime is of a kind to disturb the peace of the country or the good order of the territorial sea;

\footnotetext{
${ }^{96}$ For example, when undertaking weapon exercises on its own or with a third State. See UNCLOS art. 25 (3).

${ }^{97}$ Shearer (1986), p. 325.

${ }^{98}$ TSC arts. 19, 20, UNCLOS arts. 27, 28, Malanczuk (1997), p. 178.

${ }^{99}$ Rayfuse (2005), p. 190.
} 
(c) if the assistance of the local authorities has been requested by the master of the ship or by a diplomatic agent or consular officer of the flag State; or

(d) if such measures are necessary for the suppression of illicit traffic in narcotic drugs or psychotropic substances.

2. The above provisions do not affect the right of the coastal State to take any steps authorised by its laws for the purpose of an arrest or investigation on board a foreign ship passing through the territorial sea after leaving internal waters.

3. In the cases provided for in paragraphs 1 and 2, the coastal State shall, if the master so requests, notify a diplomatic agent or consular officer of the flag State before taking any steps and shall facilitate contact between such agent or officer and the ship's crew. In cases of emergency this notification may be communicated while the measures are being taken.

4. In considering whether or in what manner an arrest should be made, the local authorities shall have due regard to the interests of navigation.

5. Except as provided in Part XII or with respect to violations of laws and regulations adopted in accordance with Part V, the coastal State may not take any steps on board a foreign ship passing through the territorial sea to arrest any person or to conduct any investigation in connection with any crime committed before the ship entered the territorial sea, if the ship, proceeding from a foreign port, is only passing through the territorial sea without entering internal waters.

Paragraph 1 uses the phrase 'should not be exercised', while paragraph 5 uses the phrase 'may not take any steps'. The different wording illustrates the different juridical nature of the zones in which the suspected criminal offence took place. In the situation envisaged in Article 27(1), the suspected crime has happened on board a ship during its passage through the territorial sea, and thus the coastal State is entitled to exercise jurisdiction. However, the provision limits the coastal State's authority to four particular cases. It is clear that the interests of the freedom of international trade and navigation are protected unless there are significant causes to supersede them by the demands of criminal justice. ${ }^{100}$

In the situation referred in paragraph 2, it is necessary for the coastal State to have criminalised the illicit passage of WMD and related materials in its domestic legislation in order to allow the coastal State's authorities to interdict or detain ships that are passing through the territorial sea after leaving the internal waters of the coastal State.

Paragraph 5 of Article 27 regulates the situation in which the suspected crime has taken place beyond the territorial sea of the coastal State when a vessel is beyond the reach of the coastal State's criminal law. The wording of paragraph 5 does not seem to give discretion to a coastal State because the phrase 'may not' indicates a clear prohibition regarding the exercise of the coastal State's criminal jurisdiction. ${ }^{101}$

Klein argues that the coastal State's domestic legislation that criminalises the illicit passage of WMDs and related materials would overcome this particular restriction. Thus, the prevention of the proliferation of WMDs and related materials to non-State actors is in the hands of States, depending on their will to use the available legal tools. ${ }^{102}$ In addition, Logan holds the view that the protective

\footnotetext{
${ }^{100}$ Brown (1994), p. 64.

${ }^{101}$ O’Connell (1984), p. 962, Brown (1994), p. 64.

${ }^{102}$ Article 27(2), (3), Klein (2011), pp. 201-202.
} 
principle according to which a State has a right to protect itself against threatening acts done outside its territory and Article 27 are legal tools to justify the PSI in the territorial sea. Logan comes to this conclusion based on an analogous interpretation of Article 27(1) (d) relating to the illicit trafficking of drugs. ${ }^{103}$ However, although the coastal State has criminalised the illicit passage of WMDs and related materials it would also need to associate this kind of activity with the activities regarded to disturbing the peace of the coastal State or good order of its territorial sea or consequences of the crime extend to the coastal State. ${ }^{104}$

Wolfrum considers that the above-mentioned interpretation of Article 27 is problematic. Application of Article 27 requires that the crime has been committed on board the ship passing through the territorial sea and the crime disturbs the peace of the coastal State or good order of its territorial sea. This kind of interpretation of Article 27 would also make it possible to prohibit the transport of nuclear waste, as well as the transport of dangerous substances. ${ }^{105}$ This extensive interpretation of Article 27 would be problematic because it would be inconsistent with Article 23. Therefore, the mere passage of a foreign ship through the territorial sea carrying illicitly WMDs or related materials does not meet the requirements for the exercise of the criminal jurisdiction of the coastal State.

Finland is party to the most significant WMD treaties and political arrangements, as well as the SUA Conventions and the 2005 SUA Protocols. Finland has implemented them in its domestic legislation and criminalised the illicit trafficking of WMD and related materials.

In Finland, the responsibility for criminal investigation rests with the police, Customs, the Border Guard and the Defence Forces. The management and organisation of the Finnish Border Guard is within the Ministry of the Interior, from which it follows that the Border Guard's vessels and aircraft are not treated as warships. The demilitarisation regime is regulated directly by a multilevel legal framework, and Finland's sovereign rights as a coastal State are significantly restricted by the 1921 Åland Convention. These restrictions focus on the military presence in the zone.

The responsibility to conduct a criminal investigation in offences made with terrorist intent rests with the police, and they have a right to receive executive assistance, which includes also the use of military force, in the territorial waters and EEZ of Finland from the Border Guard and the Defence Forces. ${ }^{106}$ The police have the main responsibility because the use of force against the illicit trafficking of WMDs and related materials is not the use of force against the enemy according to

\footnotetext{
${ }^{103} \operatorname{Logan}(2005)$, p. 263, Klein (2011), p. 202.

${ }^{104}$ Klein (2011), p. 76.

${ }^{105}$ Wolfrum (2009), p. 91, Hakapää (1981), p. 198 refers e.g. murder on board as "other" other activities on board the vessel "which may have "external" effects".

${ }^{106}$ Border Guard Act the Finnish Collection of Decrees 178/1938 578/2005 Section 77a, 79, Laki puolustusvoimien virka-avusta poliisille the Finnish Collection of Decrees 178/1938.

781/1980 Section 1.
} 
the law of armed conflict, as there is no armed conflict, international or national. ${ }^{107}$ The police will decide case by case whether the executive assistance is requested from the Border Guard or the Defence Forces. ${ }^{108}$

The Finnish Defence Forces do not have any police powers. Regarding the area of the Alland Islands, the Finnish navy thus has no authority to board a suspected ship, to inspect the ship, to arrest the crew or to take control of any kind over the crew in the maritime zones of Finland. According to the Act on the Defence Forces Section 2 (2)(a), Defence Forces provide 'support for other authorities, including the following:

a) executive assistance to maintain public order and security, to prevent and interrupt terrorist acts, and otherwise to protect society at large'.

According to Section 79 of the Border Guard Act (578/2005), the Border Guard has the right to receive executive assistance from the Defence Forces, among other protective equipment necessary for the safe performance of a dangerous Border Guard function and equipment and the special expertise necessary to combat a security threat to a ship at sea or to passengers on board. However, the assistance does not include the use of firearms or military force.

However, the police have to take into account the international treaty arrangements related to the demilitarisation of the Aland Islands. These treaty arrangements oblige Finland to guarantee the security of the demilitarised Aland Islands. There are three different opinions concerning the interpretation of Article 4 of the 1921 Aland Convention and the presence of Defence Forces in the demilitarised zone in the case of executive assistance. ${ }^{109}$ First, the executive assistance of the Defence Forces for the operation requested by the police is under the command of the civil authority, and therefore the troop of the Defence Forces is regarded as civilian, and thus its presence is not regulated by the 1921 Aland Convention. Second, the troop of the Defence Forces is regarded as military, but the 1921 Aland Convention offers certain exceptions when considering a military presence within the zone during peacetime. Thus, the executive assistance of the Defence Forces is based on Article 4 (2)(a) of the 1921 Alland Convention, which says:

(a) In addition to the regular police force necessary to maintain public order and security in the zone, in conformity with the general provisions in force in the Finnish Republic, Finland may, if exceptional circumstances demand, send into the zone and keep there temporarily such other armed forces as shall be strictly necessary for the maintenance of order.

\footnotetext{
${ }^{107}$ Treves (2009), p. 412.

${ }^{108}$ Government Proposal HE 220/2013 vp., Laki puolustusvoimien virka-avusta poliisille the Finnish Collection of Decrees 178/1938. $781 / 1980$.

${ }^{109}$ Ministry of Defence (2014), p. 7.
} 
Thereby, the military presence does not in this kind of exceptional situation violate the limitations set on Finnish naval visits by the 1921 Aland Convention. The responsibility for the provision of executive assistance in the area of the Aland Islands regarding the Defence Forces rests mainly with the Finnish navy. The third interpretation considers the restrictions of the 1921 Alland Convention as covering the troop of the Defence Forces as well in the case of executive assistance requests by the police. ${ }^{110}$ Thus, military presence would not be allowed in the zone, even in exceptional situations. The last interpretation would mean that the police and the Border Guard could not ask for executive assistance from the Finnish navy, even when the activity that renders passage non-innocent occurs in the demilitarised zone. Regarding the illicit trafficking of WMD and related materials, the second option seems plausible in the context of the coastal State authority to enforce protective rules.

\section{Concluding Observations}

Boarding a foreign ship without permission or other authorisation is in contravention of international law. This kind of activity on the territorial waters of the Aland Islands by the Finnish military authorities, when directed at governmental ships or civilian ships believed to be carrying WMD or related materials, could be interpreted to be against the provisions of the treaty arrangements that demilitarise the sea area around the Alland Islands.

Participants of the PSI are committed to taking appropriate actions to stop and/or search, in their internal waters, territorial seas or contiguous zones, vessels that are reasonably suspected of carrying cargoes of WMDs, their delivery systems or related materials to or from States or non-State actors of proliferation concern and to seize such cargoes that are identified. The State always has a right to take interdiction operations against its own vessels. However, in the demilitarised zone of the Aland Islands, this might be problematic, even against ships flying the Finnish flag.

The 3-nautical-mile demilitarised sea area around the Alland Islands belongs to Finland's internal waters and territorial sea. Thus, Finland's authority to regulate innocent passage through the Åland Islands' territorial sea depends on the current legal framework. In the territorial sea, the enforcement of the requirements of the PSI rests on the interpretation of Article 19 (2) of UNCLOS. In spite of claims for an independent nature of the right of innocent passage, coastal States have the authority to prevent passage that is not innocent and to adopt new laws and regulations relating to passage. Taking into consideration the objective and purpose of demilitarisation and neutralisation, the Åland Islands' surrounding sea areas

$\overline{{ }^{110} \text { Ministry of Defence (2014) }}$, p. 7. 
might differ from other sea areas when it comes to the nature of peace, good order or security. When discussing the territorial waters of the Åland Islands, therefore, one should always bear in mind the interests of the wider group of countries and not just Finland. In a case concerning the illicit trafficking of WMDs and related materials through the demilitarised territorial sea area where there is solid intelligence that the intentions are threatening a party to the 1921 Åland Convention, the shipment would pose a threat of force that is not in accordance with the Convention's aim and purpose. When the passage through the territorial waters of the Åland Islands is rendered non-innocent, any enforcement measures undertaken must meet the provisions of the 1921 Åland Convention.

\section{References}

Actes de la Conférence. relative à la non-fortification et à la neutralisation des îles d'Aland, tenue à Genève, du 10 au 20 octobre 1921. (1922). Publie par les soins du Secretariat Permanent de la Société des Nations. Genève

Ahlström C (2005) The proliferation security initiative: international law aspects of the statement of interdiction principles. In: SIPRI Yearbook 2005: armaments, disarmament and international security, pp 741-765

Allen CH (2007) Matitime counterproliferation operations and the rule of law. Praeger Security International

Beck ME (2004) The promise and limits of the PSI. The Monitor 10(1):16-17. Available via, Center for International Trade and Security. http://www.uga.edu/cits/documents/pdf/monitor/ monitor_sp_2004.pdf. Accessed 3 Feb 2016

Bergin A (2005) The proliferation security initiative-implications for the Indian Ocean. Int J Mar Coast Law 20(1):85-95

Brown ED (1994) The international law of the sea, volume introductory manual

Byers M (2004) Policing the high seas: the proliferation security initiative. Am J Int Law 98 (3):526-545

Churchill RR, Lowe AV (1999) The law of the sea. Manchester University Press

Cirincione J, Williams J (2005) Putting PSI into Perspective, April 27 2005. In: Carnegie endowment for international peace. http://carnegieendowment.org/2005/04/27/putting-psiinto-perspective. Accessed 18 Feb 2016

Dixon DB (2006) Transnational shipments of nuclear materials by sea: do current safeguards provide coastal states a right to deny innocent passage? The Berkeley Electronic Press Paper 1794, pp 1-34. http://law.bepress.com/expresso/eps/1794. Accessed 9 Feb 2016

Durkalec J (2012) The proliferation security initiative: evolution and future prospects. EU Non-Proliferation Consortium Non-Proliferation Papers, pp 1-21

Fact Sheet The White House, Office of the Press Secretary 2003 September 4. http://www.state. gov/t/isn/c27726.htm. Accessed 16 Feb 2016

Fidler DP (2003) Weapons of mass destruction and international law. ASIL Insights 8(3). https://www. asil.org/insights/volume/8/issue/3/weapons-mass-destruction-and-international-law. Accessed 25 July 2016

Garvey JI (2005) The international institutional imperative for countering the spread of weapons of mass destruction: assessing the proliferation security initiative. J Conflict Secur Law 10 (2): $125-147$

Government Proposal. HE 220/2013 vp. Hallituksen esitys eduskunnalle laiksi rajavartiolain muuttamisesta sekä eräiksi siihen liittyviksi laeiksi 
Hakapää K (1981) Marine pollution in international law, material obligations and jurisdiction with special reference to the Third United Nations Conference on the law of the sea. Suomalainen Tiedeakatemia, Helsinki

Hakapää K (1988) Uusi kansainvälinen merioikeus. Lakimiesliiton Kustannus, Helsinki

Hakapää K, Molenaar EJ (1999) Innocent passage - past and present. Mar Policy 23(2):131-145

Hannikainen L (1994) The continued validity of the demilitarised and neutralised status of the Åland Islands. Zeitschrift für ausländisches öffentliches Recht und Völkerrecht 54:614-651

Harrison J (2013) Making the law of the sea, a study in the development of international. Cambridge University Press

HELCOM (2014) Annual report on shipping accidents in the Baltic Sea in 2013. HELCOM-Baltic Marine Environment Protection Commission

International Association of Lawyers Against Nuclear Arms Aotearoa New Zealand Branch (n.d.) Submission to the Select Committee on Foreign Affairs, Defence and Trade on the New Zealand Nuclear Free Zone Extension Bill. http://lcnp.org/disarmament/nwfz/submis sion\%20on\%20NWF2.htm. Accessed 21 March 2016

Jimenez Kwast P (2007) Maritime interdiction of weapons of mass destruction in an international perspective. Neth Yearb Int Law 38:163-241

Jinyuan S (2012) The proliferation security initiative (PSI) and interdiction at sea: a Chinese perspective. Ocean Dev Int Law 43(1):96-118. doi:10.1080/00908320.2012.647515

Joint Statement by the United States of America and the Union of Soviet Socialist Republics, Uniform Interpretation of Norms of International Law Governing Innocent Passage (1989). Law of the Sea Bulletin 1989(14):12-13

Joyner DH (2005) The proliferation security initiative: nonproliferation, counterproliferation, and international law. Yale J Int Law 30:507-548

Kaye S (2006) The proliferation security initiative in the maritime domain. Int Law Stud $81: 141-164$

Klein N (2011) Maritime security and the law of the sea. Oxford University Press

Kraska J (2009) Grasping "The Influence of Law on Sea Power". Naval War Coll Rev 62 (3):113-135

Lehrman TD (2004) Enhancing the proliferation security initiative: the case for a decentralized nonproliferation architecture. Virginia J Int Law 45:223-276

Lehto M (2008) International responsibility for terrorists acts. A shift towards more indirect forms of responsibility. Acta Universitatis Lapponiensis 139, Lapland University Press, Vaajakoski

Logan SE (2005) The proliferation security initiative: navigating the legal challenges. J Transl Law Policy 14(2):253-274

Malanczuk P (1997) Akehurst's Modern Introduction to International Law. Seventh revised edition. Routledge, London

McDougal MS, Burke WT (1987) The public order of the oceans. A contemporary international law of the sea. New Haven Press, New Haven

Ministry for Foreign Affairs of Finland. http://formin.fi/public/default.aspx? contentid $=325890 \&$ contentlan $=2 \&$ culture $=$ en-US. Accessed 16 Feb 2016

Ministry of Defence, Selvitys/Utredning HARE PLM001:00/2014, FI.PLM.2015-2073, $767 / 00.99 .00 / 2014$

Nordquist MH, Nandan SN, Rosenna S, Grandy NR (eds) (1993) United Nations Convention on the Law of the Sea 1982, A Commentary, Volume II. Martinus Nijhoff Publishers

O'Brien P (2012) The Åland Islands Solution. A precedent for successful international disputes settlement. http://legal.un.org/ola/media/info_from_lc/POB\%20Aalands\%20Islands\%20Exhi bition\%20opening.pdf. Accessed 26 Aug 2014

O'Connell DP (1984) In: Shearer IA (ed) The International Law of the Sea Volume II. Clarendon Press, Oxford

Pharand D (1977) International straits. Thesaurus Acroasium 7:64-100

Proliferation Security Initiative. http://www.psi-online.info/Vertretung/psi/en/01-about-psi/0about-us.html. Accessed 5 Feb 2016 
Prosser A, Scoville HJ (2004) The proliferation security initiative in perspective. Center for Defense Information June 16, 2004. http://www.cdi.org/pdfs/psi.pdf. Accessed 3 Feb 2016

Rayfuse R (2005) Regulation and enforcement in the law of the sea: emerging assertions of a right to non-flag state enforcement in the high seas fisheries and disarmament contexts. Aust Yearb Int Law 24:181-200

Remarks by the President to the People of Poland 2003 May. http://georgewbush-whitehouse. archives.gov/news/releases/2003/05/20030531-3.html. Accessed 16 Feb 2016

Ronzitti N (1990) The law of the sea and the use of force against terrorists activities. In: Ronzitti N (ed) Maritime terrorism and international law. Martinus Nijhoff, Dordrecht, pp 1-14

Shearer IA (1986) Problems of jurisdiction and law enforcement against delinquent vessels. Int Comp Law Q 35(2):320-343

Thomas TV (2009) The proliferation security initiative: towards relegation of navigational freedoms in UNCLOS? An Indian perspective. Chin J Int Law 8(3):657-680

Tornberg R (2009) Folkrättsliga aspekter på Proliferation Security Initiative. Inrädesanförande hållet vid Kungl. Örlogsmannasällskapets ordinarie sammanträde i Stockholm, pp 137-149

Treves T (2009) Piracy, law of the sea, and use of force: developments off Coast of Somalia. Eur J Int Law 20(2):399-414

US Department of State (2003) Proliferation Security Initiative: Chairman's Statement at the Third Meeting. Third Meeting of the PSI, September 3-4, 2003. http://2001-2009.state.gov/t/isn/rls/ other/25425.htm. Accessed 16 Feb 2016

US Department of State Proliferation Security Initiative. http://www.state.gov/t/isn/c10390.htm. Accessed 16 Feb 2016

Vukas B (2004). The law of the sea: selected writings. Martinus Nijhoff Publishers

Winner AC (2005) The proliferation security initiative: the new face of interdiction. Wash Q 28 (2):129-143

Wolfrum R (2009) Freedom of navigation: new challenges. In: Norquist MH, Koh TT, Moore NJ (eds) Freedom of seas, passage rights and the 1982 Law of the Sea Convention. Matinus Nijhoff Publishers, Leiden/Boston, pp 79-94

Yearbook of International Law Commission Volume II (1956)

\section{Case}

Legality of the Use by a State of Nuclear Weapons in Armed Conflict, Advisory Opinion, I. C. J. Reports 1996, p 66

Open Access This chapter is licensed under the terms of the Creative Commons AttributionNonCommercial 4.0 International License (http://creativecommons.org/licenses/by-nc/4.0/), which permits any noncommercial use, sharing, adaptation, distribution and reproduction in any medium or format, as long as you give appropriate credit to the original author(s) and the source, provide a link to the Creative Commons license and indicate if changes were made.

The images or other third party material in this chapter are included in the chapter's Creative Commons license, unless indicated otherwise in a credit line to the material. If material is not included in the chapter's Creative Commons license and your intended use is not permitted by statutory regulation or exceeds the permitted use, you will need to obtain permission directly from the copyright holder. 